\title{
THE CATALOGUE OF THE LIBRARY OF JOHN WEBSTER
}

\section{INTRODUCTORY NOTES}

In the original manuscript of the catalogue of Webster's library (Chetham MS. A.6.47), the works have been arranged according to subject and book-size with appropriate section headings. In the transcription that follows, I have attempted to preserve the original layout of the catalogue (and by implication, the library itself), but have altered the system of numeration in order to aid easy access to particular items by use of the Index. Each item is described as follows:

(i) The catalogue description with estimated value of each item (in light type). In all cases, I have reproduced original spelling, and errors, as well as the gaps in transcription where the copier was unable to read the original manuscript (presumably in Webster's handwriting), e.g., item 1164.

(ii) A full description of the work where this is known (in bold type). In most instances, it has proved impossible to identify individual editions. Wherever possible, I have tried to indicate the full range of editions which may have included that in Webster's possession.

(iii) In the case of works published in England, or in the English language, I have included in brackets the Short title catalogue number (S.T.C.) as found in: A.W. Pollard and G.R. Redgrave, A short-title catalogue of books printed in England, Scotland and Ireland, and of English books printed abroad, 1475-1640, London, Bibliographical Society, 1926. Donald Wing, Short title catalogue of books, printed in England, Scotland, Ireland, Wales and British America and of English books printed in other countries, 1641-1700, New York, Columbia University Press, 1945-51, 3 vols.

Finally, I have also included in parentheses all citations by Webster of works in his possession with the appropriate page-references from the following:

AE: Academiarum examen, or the examination of academies, London, Giles Calvert, 1654

DS: The displaying of supposed witchcraft, London, J.M., 1677

JS: The judgement set, and the bookes opened, London, R. Hartford, 1654

M: Metallographia, or, an history of metals, London, Walter Kettilby, 1671 